\author{
NATAliYa MACHYNSKA \\ Lviv Ivan Franko National University \\ ORCID: https://orcid.org/0000-0003-0309-7074
}

\title{
TRAINING OF PRIMARY SCHOOL TEACHERS IN TERMS OF THE UNIVERSITY LEVEL: THEORETICAL AND PRACTICAL CONTENT
}

\begin{abstract}
The article describes the features of formation of professional and pedagogical skills of primary school teachers in terms of a higher educational institution. The author gives definitions that reveal the nature of the meaning of the teacher's pedagogical skills. The elements of professional skills (humanistic orientation, professional competence, pedagogical skills, teaching technique) are analyzed. It is noted that humanistic orientation is one of the most important components of teaching skills in elementary schools. In the article, different values of humanistic orientations were mentioned as well. The peculiarities of the formation in the context of a systematic approach in terms of the educational process of the institution are outlined and the criteria for the formation of the professional skills are named (expediency, performance, effectiveness, optimality and creativity). There were defined key competences that determine the readiness of future students for pedagogical activities, that is, communicative competence, perceptual competence, creativity and optimism, emotional stability and mobility. Additionally, there were demonstrated different concepts of meaning "teaching skills". Different probabilities and resources of professional training for future teachers (including several levels of studying) were showed in the article.

The need to create professional readiness of students as integrative quality and an important factor for future effective educational activities is stressed. The article focuses on professional mobility as an indicator of the efficiency of formation of the professional readiness of students.
\end{abstract}

Keywords: professionalism, teaching skills, professional work of teachers, skills for teaching activities, professional readiness, professional mobility

In terms of integration of Ukraine into the European educational environment and changes in the system of the education in the context of the Bologna Process, the goal of modern education is to transform the national education system to the new concept of teaching children and young people. To achieve the set target it is 
necessary to take into account the personal potential of each individual, capable of independent scientific knowledge, development and introduction of innovative technologies, professional formation and the formation of general and professional culture, professional competence in the future in terms of higher educational establishment.

To address these challenges, there is a need for the elementary school teacher who not only received appropriate professional and pedagogical training in different types of educational institutions, but also is ready for lifelong professional growth and improvement of professional skills.

The essential feature of pedagogical work is that this activity is based on a constant process of interaction between different categories of people. This reinforces the role of personal relationships in educational activities and emphasizes the importance of moral issues.

The professional activity of a teacher is characterized by the specific feature which involves psychological and pedagogical impact on students, taking into account their age and personality, needs and interests, hobbies, spiritual world, but, at the same time, making a deliberate process management of learning and personal development.

The teacher is a specialist who has special training and professionally conducts educational work in different educational systems. Educational activity is a professional activity aimed at the formation and development of the personality of the pupils.

What properties must a primary school teacher possess to be called a teacher? What is the background of the phrase "pedagogical skills of teachers"? Certainly, any skills, including teaching ones are disclosed in activities, moreover, in effective activities. This understanding of skills is common in pedagogy. The efficiency of the process of education largely depends on the actions of the teacher who is an active participant of educational process, who immediately and multifacetedly affects each of the components of the process of education. The teacher of a primary school should make the pupil the central figure in this process. The pupil should become an active, conscious, full and independent participant. The task of the teacher is to increase pupil's motivation, to improve his/her skills, to teach him/ her to gain the effective methods of self-study, to instill a sense of subjectivity in the educational process. Only a true master of his craft can cope with this very difficult task.

This is what led to the choice of the topic of this research. The purpose is to analyze the features of formation of pedagogical skills of professionals - the teachers of primary school in terms of a higher educational establishment. 


\section{DIFFERENT ASPECTS OF PROFESSIONAL TRAINING FOR SCIENTISTS}

Teaching skills is a complex, integral phenomenon. That is the result of a clearly defined period of training in pedagogical high institution and long, continuous occupation. Pedagogical skills are closely related to the professionalism of teachers.

Professionalism is acquired during training and practice of the ability to perform the competent, professional, functional responsibilities; it is a level of skills and the art of performance of a specific type of tasks at different levels of their complexity.

There are different interpretations of the concept of teacher training. In particular, it is:

- the system of training teachers for secondary schools and other educational institutions in pedagogical universities, teacher colleges; in the broadest sense - as teaching and training of the teaching staff to work in educational institutions of all types (Koren 2013);

- a set of special knowledge, skills, work experience and behavior that enable successful work of a certain profession (Goncharenko 1997, p. 573);

- the process that is characterized by a certain level of individual teacher skills, formation of general pedagogical knowledge and skills (Kairova 1988, p. 57);

- the process of professional development of future professionals engaging students in educational activities (Abdullina 1990, p. 24).

I analyze the elements of pedagogical skills (Zyazyun 1997). In his book Science and Art of Teacher Performance, I. Zyazyun says that mastery of teaching skills is necessary for systematic training for each training session; requires constant work with the latest pedagogical and psychological literature for practical use; learning from the experience of colleagues and taking the advantage of it is useful; making the necessary individual methods such as raising voice, broadcasting technology, grammatical correctness, diction, intonation, sound power, etc. equally important. The scientist believes that the success of educational activities is determined primarily by the level of professional training instructor (Zyazyun 2001).

Humanistic orientation is the most important component of pedagogical skills. It is focused on the identity of another person, on the establishment of the highest spiritual values, moral norms of behavior and relationships with the help of word and activity. This is a manifestation of the ideology of professional teacher, his attitude to the educational value of reality, its purpose, content, tools and participants.

The basis of humanistic orientation of the elementary school teacher consists of his value orientation:

- of himself - self-affirmation (I am qualified, demanding, a real teacher);

- of the means of pedagogical influence (the most important for the teacher - the curriculum, activities and methods of their presentation); 
- of the pupil (adaptation of the children's group in the real world);

- of the purpose of educational activities (humanistic strategy - it is a help for a pupil in his personal development).

For the teacher, the leading focus is on the main goal, providing all other harmonic coherence: the humanization of the activity, worthy self-affirmation, expediency of means, taking into account the needs of pupils. The professional skills of teachers start to appear only if a sense of responsibility to the future, sense of purpose and a great love for children are present.

The teacher's knowledge refers, on the one hand, to the disciplines he teaches, and on the other - to students' attitudes towards learning. In preparation for the lesson, the teacher ponders its contents, methodology, takes into account the perception of the particular age, class, personal capabilities. Thus, the content of professional competence involves the knowledge of the subject, its teaching methods, pedagogy and psychology.

An important element in the structure of pedagogical skills is the ability to perform educational activities. They depend on the peculiarities of mental processes that contribute to successful educational activities and act as the individual preconditions for the positive activity and professional development.

Based on the results of psychological and pedagogical research, we can identify the following key skills for teaching activities:

1) communication - the ability of professional teacher, characterized by the need to communicate, willingness to contact easily. It causes positive emotions;

2) perceptual abilities - professional insight, vigilance, pedagogical intuition, the ability to perceive and understand another person;

3) dynamic personality - the ability to actively influence another person;

4) emotional stability - the ability to control himself regardless of the strength of external factors that provoke an emotional breakdown;

5) the optimistic prediction means predicting personality development with a focus on its positive features, and transforming the entire structure of personality through positive impact on quality;

6) creativity - the ability to create, to generate unusual ideas, depart from conventional structures, quickly resolve problematic situations.

The ability to perform educational activities can be evaluated based on how quickly vocational and educational training happens.

Another element of pedagogical skills is the pedagogical technique as a form of teacher's behavior. Knowledge, focus and capability without skills, without actions does not guarantee great results. Educational technology is the ability to use the psychophysical device as a tool of educational influence. These are the 
techniques of self-control (body, mood, speech, attention and imagination) and methods of influence on others (verbal and non-verbal means).

The analyzed elements of pedagogical skills allow one to find out the consistency of this phenomenon in educational activity. The high level of skills provides a new quality of work of all teachers. A professional position is formed, which accumulates higher levels of directional knowledge and readiness for action; advanced knowledge becomes a tool for self-reflection; high level of skills promotes self-revelation of personality and improvement of teaching techniques provides the search for results and an adequate plan.

The criteria for the excellence of the teacher are: expediency (in direction), productivity (results), dialogic attitude (nature of the relationship with the students), optimality (in the choice of means), creativity (the content of the activity).

We believe that teaching skills is a phenomenon that is characterized by regularity, consistency, integrated indexes of theoretical and practical readiness to perform professional and educational functions.

\section{SEVERAL LEVELS OF FUTURE SPECIALISTS’ TRAINING}

Elementary level. A teacher possesses only a few professional qualities. The most common is the possession of knowledge to perform educational actions and the possession of the knowledge of the subject to be taught. However, due to the lack of focus on student's development, the ability to create a dialogue, the result of the educational work of the teacher, is very low.

Basic level. The teacher has the basics of pedagogical skills. The teaching activities are humanistic-oriented. The relations with students and colleagues develop on the basis of a positive attitude. The teacher organizes well educational process in the classroom providing good knowledge of the subject. This level is usually reached at the end of study in the higher educational establishment.

The level of perfection. It is characterized by clear action orientation of the teacher and his high quality, dialogical interaction in communication. The teacher is planning and organizing his activities for a long period of time, with the main task of development of the student's personality.

Creative level. It is characterized by initiative and creative approach to the process of the organization of professional activity. A teacher originally designs his own pedagogically appropriate methods of interaction, building activities based on the reflexive analysis. At this level, the unique style of professional activity is formed.

The formation of pedagogical skills begins in terms of the educational process of higher educational institution. The impact of this long process depends on 
many factors, including: sustainability of systematic and organized educational process; the semantic content of subjects and continuity of teaching practice; professionalism and competence of teachers and others.

The task of the higher educational institution is to help the students to learn the basics of pedagogical skills for informed and productive beginning of professional activity, that involves the formation of humanistic orientation, mastery of fundamental knowledge, developing of teaching skills, laying the foundations of technology cooperation, training for professional analysis of a wide variety of teaching situations. All this should be reflected in the current professional readiness of students.

The professional readiness of a student is an integrative and personal quality essential to prerequisite for effective work after graduation. The professional readiness of a student helps a young specialist to successfully carry out his duties, to use the knowledge properly, to experience and preserve self-control and to rebuild oneself in case of unforeseen obstacles (Onushkyn, Ogarev 1995).

Humanistic orientation as an integral component of pedagogical skills, and rate of formation of professional readiness is a manifestation of the ability of the specialist to see "big tasks" in small activities. This allows one to evaluate professional and educational activities in terms of not only direct but also indirect results, meaning positive changes in personal life and personality structure of the pupils. The changes are partly organized by the teacher, who is responsible for the quality of the educational process.

As a professionally important quality, professional readiness of the individual student is a complex psychological formation that includes the following components: motivation, orientation, operation, strong will, and evaluation. The sufficient development of these components and their complete unity performs the role of the indicator of the high level of the graduate student's professional readiness for professional activity.

One of the criteria of efficiency of professional readiness of students is professional mobility, which depends on the student's willingness not to engage in one activity, but in many; to understand the principles of one particular or different social communities; to coordinate different types of activities in different social communities with the necessary preservation of his own "I - Myself". The professional mobility should not be the result of mastering one type of readiness for the professional activities, but of historically formed, generalized forms and methods of work. For that it is essential to create, in the process of learning, the dialogue of different cultures, to form a cultural-historical type of schools and higher educational establishment.

An important feature of the professional pedagogical knowledge that provides the formation of the mobility of future teachers in the conditions of the university, 
is their complexity, which requires the teacher's ability to synthesize material for the successful solution of educational problems, to analyse teaching situations that necessitate the understanding of the psychological essence of phenomena and the choice of means of interaction. When solving the problem, every teacher updates the entire system of teacher pedagogical knowledge that acts as a complex structure. The formation of a complex of practical skills to solve educational problems and situations is ensured through the diversification of content of subjects, provided by the curriculum for future primary school teachers training in terms of pedagogical higher education institution (Kulyutkina, Sukhobskaya 1981).

The knowledge of the teacher is not just the amount of learned discipline but personal influence on conscious system, where there is place for estimates, or critical views. "The main thing in life is not just knowledge, but that harmony which appears when good knowledge lives in a good soul, the philosophy that defines the man, his world view" (Boychenko, Sukhomlinsky 2014).

Modern schools need teachers that possess: pedagogical orientation, professional competence, harmony of developed intelligence, moral and aesthetic maturity, scientific potential, continuous improvement. It is the group of teachers that should be trained in a higher educational institution, paying particular attention to achieving and mastering pedagogical skills.

Thus, it should be noted that the formation and development of professional skills of primary school teachers has its origins in conditions of higher educational institutions and teaching occurs within a systemic approach. The implementation of all components of vocational and educational excellence provides a qualitative educational process in elementary school, the dialogue between those who teach and those who learn, creative self-development and self-realization of teachers in the professional and personal development of each pupil.

Further areas of research are seen in the development of integrated courses and their implementation in the educational process of training of future elementary school teachers in terms of higher educational establishment.

It is difficult to overestimate the role of the modern primary education and primary school teacher appointment as a teacher, which lays the foundation for development and self-identity of the child throughout life, its cultural identification, acquisition and assimilation of emotionally valuable experience. Changing values and goals of modern education, specifying its focus on personal development in the context of culture led to a significant change in views on the content and technology of primary education and primary school teacher training.

Due to the special requirements for the teacher, there is an objective need to develop new models qualifying performance of graduates of pedagogical universities. They include the requirements for teacher professional readiness to imple- 
ment the new program of individual student performance concerning his social maturity. Among these indicators, one can find intellectual, philosophical, ethical, legal, political, aesthetic, cultural, labor, environmental, and physical training. However, all these fields should be approached holistically.

\section{REFERENCES}

Абдулина, А.А., 1990, Общепедагогчческая подготовка учителя в системе высшего педагогического образования. Москва: Просвещение.

Бойченко, O.I., Сухомлинський, B.О., 2014, Про професійний саморозвиток майбутніх учителів початкової школи. Науковий вісник Миколаївського національного університету імені В.О. Сухомлинського: Педагогічні науки, T. 1, № 47 (114), pp. 32-34.

Гончаренко, С.У., 1997, Украйнський педагогічний словник. Київ: Лібід.

Зязюн, І.А., 2001, Наука і мистеитво педагогічної діі. «Професійна освіта: педагогіка і психологія», Т. 3, pp. 357-380.

Зязюн, І.А., Сагач, Г.М., 1997, Краса педагогічної діi. Київ: Вища школа.

Каирова, А.И. (ред.), 1988, Педагогическая энииклопедия. Москва: Советская энциклопедия, Т. 3.

Корень, А., Зміст загальнопедагогічної підготовки майбутнього вчителя як наукова проблема, http://nbuv.gov.ua/UJRN/Vird_2013_30_15 [access: 15.02.2017]. Кулюткина, Ю.Н., Сухобская, Г.С., 1981, Моделирование педагогических ситуаций. Москва: Просвещение.

European Adult Learning Glossary, Level 1, https://ec.europa.eu/epale/sites/epale/files/ adultglossary1_en.pdf [access: 15.02.2017].

Онушкин, В.Г., Огарев, Е.И., 1995, Образование взрослых. Междисииплинарный словарь терминологии. Санкт-Петербу́рг-Воронеж.

PRZYGOTOWANIE NAUCZYCIELI SZKOŁY PODSTAWOWEJ

NA POZIOMIE UNIWERSYTECKIM: ASPEKT TEORETYCZNO-PRAKTYCZNY

Abstrakt: W artykule rozpatrzono właściwości kształtowania nawyków zawodowopedagogicznych nauczycieli klas podstawowych w szkole wyższej. Autorka proponuje określenia, które ujawniają istotę pedagogicznej działalności nauczyciela, w szczególności: działalności zawodowej, wyszkolenia zawodowego, nawyków pedagogicznych. Ponadto przeanalizowano elementy mistrzostwa zawodowego nauczyciela szkoły podstawowej, takie jak: humanistyczna 
orientacja, kompetencja zawodowa, nawyki pedagogiczne, metodyka nauczania. Zaznaczono, że humanistyczne kierunki stanowią jeden z najważniejszych składników pedagogicznego mistrzostwa nauczyciela szkoły podstawowej. Autorka wyodrębniła składowe wartości orientacji nauczyciela (poczucie własnej godności, środki pedagogicznego wpływu, osoba ucznia, humanistyczna strategia działalności), określiła też właściwości kształtowania kompetencji zawodowych nauczycieli szkoły podstawowej w kontekście systemowego procesu edukacyjnego uczelni. Podkreślone zostały kluczowe kompetencje, które określają gotowość przyszłych studentów do realizacji działalności pedagogicznej (komunikatywność, percepcja, kreatywność, optymizm, odporność emocjonalna, mobilność).

Słowa kluczowe: profesjonalizm, nawyki pedagogiczne, działalność zawodowa nauczycieli, gotowość zawodowa, mobilność zawodowa 